\title{
Lifestyle changes in long term survivors of acute myocardial infarction
}

\author{
R R WEST AND D A EVANS \\ From the Department of Epidemiology and Community Medicine, University of Wales College of Medicine, Cardiff
}

SUMMARY A retrospective questionnaire and interview study of 10 year survivors of uncomplicated myocardial infarction examined smoking, diet, exercise, weight, medication, and treatment since discharge from hospital in 1973-4 and made comparisons with controls (using the same questionnaire) and with normal populations (as reported by others). Long term survivors of myocardial infarction previously smoked more than controls; made more dietary changes than controls; and presently eat less butter, sugar, cake, and biscuits and drink less milk than controls; previously weighed more than controls; exercised less than controls both previously and presently; use more 'non-cardiac' as well as 'cardiac' drugs than controls; and are more depressed and more anxious than controls.

Survival after acute myocardial infarction depends on age, size of infarct, severity of cardiac dysfunction, and history of previous myocardial damage. ${ }^{12}$ Trials have shown that survival may be improved by long term medication by beta blockade, ${ }^{34}$ aspirin $^{5}$ or sulfinpyrazone. ${ }^{6}$ The prognosis may be influenced by reductions in blood pressure, cigarette smoking, and serum cholesterol. ${ }^{78}$ These important primary risk factors for heart disease are dependent to some extent on habits and lifestyles. Several studies have suggested that stopping smoking after myocardial infarction can be beneficial. ${ }^{9-13}$

A cohort of 742 patients admitted to hospitals throughout Wales with uncomplicated myocardial infarction has been followed up for 10 years in a detailed analysis of long term survival of a randomised multicentre trial comparing early and late mobilisation. ${ }^{14} \mathrm{~A}$ retrospective questionnaire and structured interview study was undertaken at the time of this late follow up to ask about smoking habits, diet, lifestyle, exercise, weight, medication, and treatment since discharge from hospital in 1973-4. The questions in this retrospective study were mostly "standard" questions used in population based studies so that the responses of our long term survivors could be compared with those of "normals". The questionnaire was administered also to a "control" group of men and women selected from the same geographic regions of Wales as the majority of survivors. We report comparisons of lifestyle and changes in lifestyle between long term survivors of uncomplicated myocardial infarction and control subjects and normal subjects as reported by others.

\section{Methods}

In 1973-4, 742 patients were entered into the Welsh trial of mobilisation. ${ }^{14}$ These were 631 men and 111 women aged under 70, who were admitted to one of 12 participating hospitals with acute myocardial infarction (diagnosed on the basis of two of three criteria: typical clinical history, electrocardiographic evidence of "very probable" infarction according to WHO criteria, and serum levels of "cardiac" enzymes more than twice the laboratory normal) and who were without clinical complications on the fifth day after the onset of cardiac pain. Eighty eight were aged $₹ 44$, 240 aged 45-54, 304 aged 55-64, and 110 aged 65-69. Previous medical histories of myocardial infarction were reported in 18, of hypertension in 82 , and of diabetes in 18. The one year survival of these patients was $89 \%$, and the annual mortality thereafter was approximately $4 \%$. At the end of 10 years $70 \%$ of patients admitted when aged $₹ 44,60 \%$ of those aged $45-54,48 \%$ of those aged $55-64$, and $38 \%$ of those aged $65-69$ were still alive.

A retrospective study of these survivors was designed to enquire into long term medication after discharge from hospital and into lifestyle and lifestyle changes which might influence long term survival. This took the form of a postal questionnaire which asked about smoking, diet, weight, exercise, drug 
treatment, and further cardiovascular events. The questionnaire used "standard" questions whenever possible to allow comparisons with other reported studies, for example, the MRC Caerphilly study of prevalence of and risk factors for ischaemic heart disease. $^{15}$

The questionnaire asked about present smoking, past smoking, whether the patient had reduced smoking and, if so, when, for what reason, and by what amount. Cigarette smoking was divided into four bands: very light smokers, $1-4$ per day; light smokers, 5-14 per day; medium smokers, 15-24 per day; and heavy smokers, $25+$ per day. Cigar and pipe smoking were included, one cigar being counted equivalent to two cigarettes (all cigar smokers smoked small cigars) and $28 \mathrm{~g}$ (loz) tobacco equivalent to 28 cigarettes. Patients were classed as having reduced their smoking in this analysis only if they had changed by at least one band. Similar sets of questions were asked about weight, exercise and diet, and particular items of diet. Dietary questions asked about usual consumption in terms of number of days per week usually eaten or drunk for 14 specific foods (butter, margarine, cheese, milk, eggs, cake/biscuits, pastry, chips, fried food, vegetables, salad, fruit, sugar, salt). Both "closed" questions seeking yes or no or a number and "open" questions allowing free responses were included in each section. The questionnaire asked for details of present and past medication in two year bands since the index myocardial infarction in 1973-4. Drugs were categorised into 15 groups using the British National Formulary. Patients were also asked about further cardiovascular events which they had experienced (further myocardial infarction, stroke, heart surgery, thrombosis excluding stroke, and hospital admission for other cardiovascular disease) in two year bands since 1973-4. The anxiety and depression scales of the Crown-Crisp experiential index were included to obtain a present day score for each patient. ${ }^{16}$

The questionnaire was piloted on patients attending cardiology clinics at the teaching hospital, who had experienced myocardial infarction some 10 years previously (while aged under 70) but who had not been admitted to the trial. It was well understood, and very few changes were found to be necessary. Questionnaires were posted to all 397 long term survivors, with up to two reminders as necessary: the final reminder was followed by a personal telephone call whenever possible. The reliability of questionnaire answers was assessed by means of a semi structured interview carried out on a random sample of 100 questionnaire responders. The coefficients of agreement between questionnaire and interview answers were calculated for all questions. A comparison group of 460 "controls" was selected randomly from lists provided by Family Practitioner Committees (FPCs) in the areas of Wales where most survivors resided. These lists were of people aged $65+$ in North Wales and of people aged 55+ in South Wales which resulted in controls being slightly older than survivors. "Controls" were not pursued as vigorously as survivors, and the questionnaire was posted only once. The data so obtained supplemented data from other studies, published and unpublished, for comparisons of habits and lifestyles between survivors and "normals" and provided comparisons ("controls") for reported changes over the preceding decade of habits and lifestyles. Statistical comparisons were by chi square test.

\section{Results}

The questionnaire was completed and returned by 349 survivors (response rate $88 \%$ ). The structured interview of a randomly selected sample of 100 responders was achieved for all 100 . The reliability of questionnaire responses is indicated by the coefficients of agreement between questionnaire and interview answers: for example, the coefficient of agreement with respect to the recall of smoking change of one band or more within the past 10 years was $88 \%$; for change of diet it was $80 \%$; for regular eating of butter it was $85 \%$, of cheese $89 \%$, of sugar $84 \%$, and of fruit $79 \%$. Completed questionnaires were returned by 277 controls, with an apparent response rate of $60 \%$ if FPC lists were up to date and accurate: however, as usual, the FPC lists were not up to date and accurate, and several questionnaires were returned marked "deceased" or "not known at this address." Since the primary purpose of the study was to gain information about infarct survivors and since data from "controls"

Table 1 Smoking habits of survivors and controls in 1973-4 and in 1983-4.

\begin{tabular}{lcrr}
\hline & Cigarettes smoked/day & $\begin{array}{c}\text { Survivors } \\
n=349\end{array}$ & $\begin{array}{c}\text { Controls } \\
n=277\end{array}$ \\
\hline 10 years ago & & & \\
& None & $105(30)$ & $129(47)$ \\
& $1-4$ & $7(2)$ & $12(4)$ \\
& $5-14$ & $45(12)$ & $47(17)$ \\
& $15-24$ & $96(28)$ & $62(22)$ \\
Present & $25+$ & $96(28)$ & $27(10)$ \\
& \multicolumn{4}{c}{} \\
& None & $209(60)$ & $183(66)$ \\
& $1-4$ & $24(7)$ & $20(7)$ \\
& $5-14$ & $68(19)$ & $43(15)$ \\
& $15-24$ & $35(10)$ & $24(9)$ \\
& $25+$ & $13(4)$ & $7(3)$ \\
& ns & \\
\hline
\end{tabular}

Percentages shown in parentheses 
served to supplement data from "normals" in other studies, controls were not interviewed.

Smoking habits are compared in table 1 . Ten years ago (at the time of myocardial infarction for survivors) survivors smoked significantly more heavily than controls, but present smoking of survivors was not significantly different from that of controls. Significantly more survivors than controls reduced their smoking during the last 10 years by one band or more, reduced longer ago (soon after their myocardial infarction) and for reasons which were more "medical" (many were directly related to their myocardial infarction) (table 2). Of those long term survivors who smoked at the time of infarction, $43 \%$ subsequently gave up and a further $35 \%$ reduced smoking. These changes are of the same order as those reported in other long term follow up studies. ${ }^{10}{ }_{-} 13$ Furthermore, the proportion of survivors who reported present smoking was significantly lower than in the MRC Caerphilly study (58\%) and those who smoked were lighter smokers than in the Caerphilly study. ${ }^{17}$

Changes in the diets of survivors and controls are compared in table 3. Many more survivors reduced high fat foods, dairy products, and high carbohydrate foods and increased fruit, vegetables, fibre, lean meat, and fish. Significantly more survivors $(63 \%)$ reported a change of diet during the past 10 years, more reported the change longer ago (9-10 years ago) and on medical advice (particularly because of their myocardial infarction) (table 4). Replies to the "closed" questions on present estimated consumption of 14 named foods showed that survivors now

Table 2 Changes in smoking habits of survivors and controls since 1973-4

\begin{tabular}{|c|c|c|}
\hline & $\begin{array}{l}\text { Survivors } \\
n=349\end{array}$ & $\begin{array}{l}\text { Controls } \\
n=277\end{array}$ \\
\hline $\begin{array}{l}\text { Never smoked or gave up before } 1973-4 \\
\text { Unchanged } \\
\text { Reduced by } 1 \text { band } \\
\text { Reduced by } 2 \text { or more bands } \\
\text { Gave up }\end{array}$ & $\begin{array}{r}105(30) \\
53(15) \\
54(16) \\
33(9) \\
104(30)\end{array}$ & $\begin{array}{r}129(47) \\
60(22) \\
25(9) \\
9(3) \\
54(19)\end{array}$ \\
\hline $\begin{array}{l}\text { Time of smoking change } \\
<2 \text { years ago } \\
3-8 \text { years ago } \\
9-10 \text { years ago } \\
\text { Not stated }\end{array}$ & $\begin{array}{r}13(4) \\
36(10) \\
130(37) \\
12(3)\end{array}$ & $\begin{array}{r}17(6) \\
46(17) \\
20(7) \\
5(2)\end{array}$ \\
\hline \multicolumn{3}{|c|}{$p<0.001$} \\
\hline $\begin{array}{l}\text { Reasons for smoking change } \\
\text { Myocardial infarction } \\
\text { Health } \\
\text { Cost } \\
\text { Medical advice } \\
\text { Thought it wise } \\
\text { Not specified }\end{array}$ & $\begin{array}{l}74(21) \\
27(8) \\
66(2) \\
58(17) \\
5(1) \\
21(6)\end{array}$ & $\begin{array}{l}2(1) \\
25(9) \\
15(5) \\
12(4) \\
14(5) \\
20(7)\end{array}$ \\
\hline & & \\
\hline
\end{tabular}

Table 3 Principal diet changes in survivors and controls

\begin{tabular}{lcc}
\hline & $\begin{array}{l}\text { Survivors } \\
n=349\end{array}$ & $\begin{array}{l}\text { Controls } \\
n=277\end{array}$ \\
\hline $\begin{array}{l}\text { Reduced fats } \\
\text { butter }\end{array}$ & $127(36)$ & $23(8)^{* * *}$ \\
milk/cheese & $73(21)$ & $14(5)^{* * *}$ \\
bread & $78(22)$ & $5(2)^{* * *}$ \\
potatoes & $55(16)$ & $16(6)^{* * *}$ \\
cake/pastry & $49(14)$ & $11(4)^{* * *}$ \\
sugar & $67(19)$ & $13(5)^{* * *}$ \\
eggs & $78(22)$ & $13(5)^{* * *}$ \\
fatty/red meats & $72(21)$ & $7(3)^{* * *}$ \\
Increased fruit & $59(17)$ & $19(7)^{* * *}$ \\
vegetables/salads & $70(20)$ & $19(7)^{* * *}$ \\
fibre & $105(30)$ & $25(9)^{* * *}$ \\
fish/lean meat & $47(14)$ & $19(7)^{* * *}$ \\
\hline
\end{tabular}

$* * p<0.01 \quad * * * p<0.001$

Table 4 Changes in diet of survivors and controls

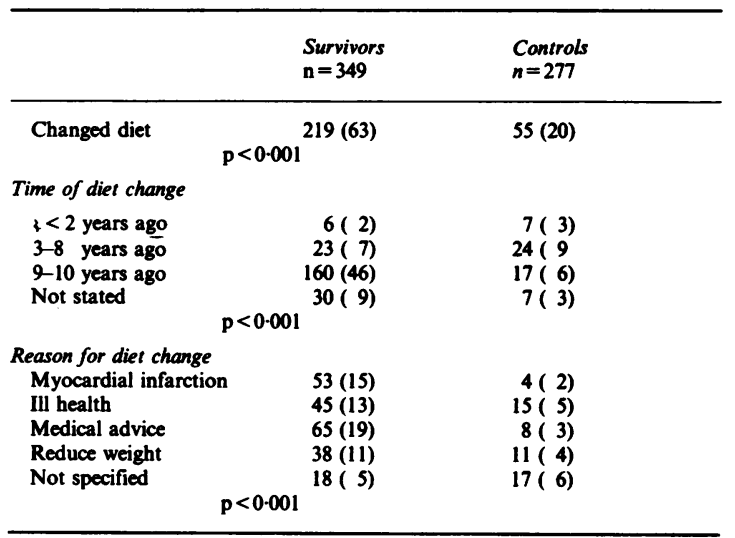

Table 5 Consumption of named foods by survivors and controls

\begin{tabular}{|c|c|c|}
\hline & $\begin{array}{l}\text { Survivors } \\
n=346\end{array}$ & $\begin{array}{l}\text { Controls } \\
n=274\end{array}$ \\
\hline \multicolumn{3}{|l|}{ Present regular use } \\
\hline Butter & $143(41)$ & $148(54)^{* * *}$ \\
\hline Hard margarine & $38(11)$ & $38(14)$ \\
\hline Soft margarine (unspecified) & $81(23)$ & $78(28)$ \\
\hline Soft margarine (polyunsaturated) & $104(30)$ & $43(16)^{* * * *}$ \\
\hline Low fat spread & $35(10)$ & $27(10)$ \\
\hline \multicolumn{3}{|l|}{$\begin{array}{l}\text { Foods consumed on } 4 \text { or more } \\
\text { days per week }\end{array}$} \\
\hline Cheese & $66(19)$ & $66(24)$ \\
\hline Milk & $210(61)$ & $208(76) * * *$ \\
\hline Eggs & $51(15)$ & $50(10)$ \\
\hline Fruit & $188(54)$ & $150(55)$ \\
\hline Vegetables & $250(72)$ & $208(76)$ \\
\hline Salads & $59(17)$ & $53(19)$ \\
\hline Cake/biscuits & $116(34)$ & $145(53) * *$ \\
\hline Pastries & $25(7)$ & $34(12)^{*}$ \\
\hline Chips & $17(5)$ & $12(4)$ \\
\hline Fried food & $25(7)$ & $28(10)$ \\
\hline Sugar & $113(33)$ & $124(45)^{* *}$ \\
\hline Salt added at table & $155(45)$ & $127(46)$ \\
\hline
\end{tabular}


regularly eat less butter and more polyunsaturated fat margarines than controls and that survivors drink milk and eat biscuits, cake, pastries, and sugar significantly less frequently than controls (table 5). Since the dietary questions were based on those of the MRC Caerphilly study, which were validated against weighed dietary intakes, ${ }^{18}$ some comparisons of present reported intakes of specific foods could be made with men and women in the Caerphilly study. Survivors reported eating significantly less high fat foods (eg, butter and fried foods and using animal fat for frying), eggs, sugar, and milk and significantly more polyunsaturated fats (eg, margarine and oil for frying) than normal subjects in the Caerphilly study. ${ }^{17}$ These dietary changes among survivors compared with controls demonstrate a reduction of total fat intake and a decrease in polyunsaturated/saturated $(\mathrm{P} / \mathrm{S})$ fat ratio, and the comparison with normal subjects demonstrates a lower total fat intake or a lower $\mathbf{P} / \mathbf{S}$ ratio among infarct survivors.

Table 6 compares the body mass indices of male and female survivors and controls in 1973-4 ind in 1983. In 1973-4 more survivors were overweight whereas in 1983 their body mass indices were similar to those of controls. Changes in body weight of survivors and controls during the past 10 years are compared in table 7. Significantly more survivors $(50 \%)$ than controls $(22 \%)$ reduced their weight during the past 10 years and more reduced by large amounts. More survivors reduced weight longer ago ( $9-10$ years ago, soon after their myocardial infarction) and more

Table 6 Body mass index of survivors and controls in 1973-4 and in 1983

\begin{tabular}{|c|c|c|}
\hline & Survivors & Controls \\
\hline $\begin{array}{l}\text { Male body mass index in } 1973-4 \\
<19 \text { (underweight) } \\
20-22 \text { (normal) } \\
23-25 \text { (normal) } \\
26-28 \text { (overweight) } \\
29+\text { (obese) }\end{array}$ & $\begin{array}{r}n=277 \\
6(2) \\
45(16) \\
102(37) \\
70(25) \\
54(20)\end{array}$ & $\begin{array}{l}n=233 \\
12(5) \\
61(26) \\
92(40) \\
52(22) \\
16(7)\end{array}$ \\
\hline $\begin{array}{l}\text { Male body mass index in } 1983 \\
<19 \text { (underweight) } \\
20-22 \text { (normal) } \\
23-25 \text { (normal) } \\
26-28 \text { (overweight) } \\
29+\text { (obese) }\end{array}$ & $\begin{array}{r}9(3) \\
61(22) \\
131(48) \\
56(20) \\
20(7) \\
\text { ns }\end{array}$ & $\begin{array}{l}12(5) \\
57(25) \\
96(41) \\
52(22) \\
16(7)\end{array}$ \\
\hline $\begin{array}{c}\text { Female body mass index in 1973-4 } \\
<18 \text { (underweight) } \\
19-24 \text { (normal) } \\
25+\text { (overweight) }\end{array}$ & $\begin{array}{r}(n=56) \\
3(5) \\
26(47) \\
27(48) \\
n\end{array}$ & $\begin{array}{c}(n=31) \\
3(10) \\
19(61) \\
9(29\end{array}$ \\
\hline $\begin{array}{l}\text { Female body mass index in } 1983 \\
1-18 \text { (underweight) } \\
19-24 \text { (normal) } \\
25+\text { (overweight) }\end{array}$ & $\begin{array}{r}4(7) \\
28(50) \\
24(43)\end{array}$ & $\begin{array}{r}2(6) \\
22(71) \\
7(23)\end{array}$ \\
\hline
\end{tabular}

Table 7 Changes in weight of survivors and controls

\begin{tabular}{|c|c|c|}
\hline & $\begin{array}{l}\text { Survivors } \\
n=346\end{array}$ & $\begin{array}{l}\text { Controls } \\
n=276\end{array}$ \\
\hline $\begin{array}{l}\text { Increased weight by } 29+\text { lb } \\
\text { Increased weight by } 15-28 \mathrm{lb} \\
\text { Increased weight by } 7-14 \mathrm{lb} \\
\text { Unchanged since } 1973-4 \\
\text { Reduced weight by } 7-14 \mathrm{lb} \\
\text { Reduced weight by } 15-28 \mathrm{lb} \\
\text { Reduced weight by } 29+\mathrm{lb}\end{array}$ & $\begin{array}{r}7(2) \\
25(7) \\
21(6) \\
121(35) \\
50(15) \\
76(22) \\
46(13)\end{array}$ & $\begin{array}{r}3(1) \\
27(10) \\
24(9) \\
161(58) \\
31(11) \\
23(9) \\
6(2)\end{array}$ \\
\hline $\begin{array}{l}\text { Time of weight loss } \\
<2 \text { years ago } \\
3-8 \text { years ago } \\
9-10 \text { years ago } \\
\text { Unstated }\end{array}$ & $\begin{array}{r}10(3) \\
31(9) \\
107(31) \\
24(7)\end{array}$ & $\begin{array}{r}14(5) \\
26(10) \\
14(5) \\
6(2)\end{array}$ \\
\hline $\begin{array}{l}\text { Reason for weight loss } \\
\text { Myocardial infarction } \\
\text { Bad health } \\
\text { Medical advice } \\
\text { Special diet } \\
\text { Not specified }\end{array}$ & $\begin{array}{l}46(13) \\
21(6) \\
34(10) \\
33(10) \\
38(11)\end{array}$ & $\begin{array}{r}4(1) \\
21(8) \\
5(2) \\
7(3) \\
23(8)\end{array}$ \\
\hline
\end{tabular}

reduced for "medical" reasons (because of their myocardial infarction) or in association with a change of diet.

The self perceived exercise ratings of survivors and controls, compared with the average for their age, in $\varnothing$ 1973-4 and in 1983, are summarised in table 8. Ten years ago survivors reported taking slightly less $\varnothing$ exercise than controls, while in 1983 survivorso reported taking consistently less exercise than $\overrightarrow{0}$ controls. The physical activities normally enjoyed (or undertaken) in 1973-4 and in 1983 showed that more survivors than controls had decreased their participation in vigorous activities (eg, gardening, running, and swimming) while both survivors and controls had increased their participation in gentle physical exercise, eg, golf and bowls. Significantly more survivors $(53 \%)$ changed their exercise during

Table 8 Self perceived exercise ratings of survivors and controls in 1973-4 and in 1983

\begin{tabular}{lrr}
\hline $\begin{array}{l}\text { Exercise rating 10 years } \\
\text { previously (recalled) }\end{array}$ & $\begin{array}{c}\text { Survivors } \\
n=340\end{array}$ & $\begin{array}{l}\text { Controls } \\
n=270\end{array}$ \\
\hline Much less & $35(10)$ & $25(9)$ \\
Less & $53(16)$ & $29(11)$ \\
Average & $179(53)$ & $155(57)$ \\
More & $41(12)$ & $50(19)$ \\
Much more & $28(8)$ & $8(3)$ \\
Unknown & $4(1)$ & $3(1)$ \\
& $p<0.01$ & $39(14)$ \\
Exercise rating in 1983 & & $38(14)$ \\
Much less & $81(24)$ & $134(50)$ \\
Less & $62(18)$ & $49(18)$ \\
Average* & $152(45)$ & $10(4)$ \\
More & $36(10)$ & \\
Much more & $9(3)$ & \\
& $\mathrm{p}<0.005$ & \\
\hline
\end{tabular}

- Average for age on self perceived exercise rating 
the past 10 years $(44 \%$ reduced and $9 \%$ increased their exercise), changed longer ago ( $9-10$ years ago, ie, soon after their infarction) and changed mainly because of ill health compared with controls. Those controls who changed their exercise ( $29 \%$ reduced, $6 \%$ increased) did so more recently and usually because of retirement (table 9).

Drug use is compared in table 10: survivors reported significantly higher present use of diuretics, beta blockers, and nitrates ("heart drugs") but also of other drugs not specifically associated with cardiovascular disease, for example, non-steroidal anti-inflammatory drugs, major and minor tranquillisers, and a miscellaneous group containing other analgesics, anti-asthmatics, and drugs for digestive disorders. The past use of these drug groups was also significantly higher among survivors than controls.

More survivors reported further cardiovascular events since myocardial infarction in 1973-4 than did controls for the comparable period, although 28

Table 9 Changes in exercise among survivors and controls

\begin{tabular}{|c|c|c|}
\hline & $\begin{array}{l}\text { Survivors } \\
n=340\end{array}$ & $\begin{array}{l}\text { Controls } \\
n=276\end{array}$ \\
\hline $\begin{array}{l}\text { Increased exercise } \\
\text { Exercise unchanged } \\
\text { Reduced exercise }\end{array}$ & $\begin{array}{l}30(9) \\
159(47) \\
151(44) \\
1\end{array}$ & $\begin{array}{r}16(6) \\
180(65) \\
80(29)\end{array}$ \\
\hline $\begin{array}{l}\text { Time of exercise change } \\
<2 \text { years ago } \\
3-8 \text { years ago } \\
9-10 \text { years ago } \\
\text { Not stated }\end{array}$ & $\begin{array}{r}8(2) \\
46(14) \\
112(33) \\
15(4)\end{array}$ & $\begin{array}{l}20(7) \\
51(19) \\
17(6) \\
8(3)\end{array}$ \\
\hline $\begin{array}{l}\text { Reason for exercise change } \\
\text { Myocardial infarction } \\
\text { Retirement } \\
\text { Medical advice } \\
\text { Breathlessness } \\
\text { Ill health } \\
\text { To keep in shape } \\
\text { Not specified }\end{array}$ & $\begin{array}{r}49(14) \\
8(2) \\
12(4) \\
15(5) \\
55(16) \\
17(5) \\
25(7)\end{array}$ & $\begin{array}{r}9(3) \\
29(10) \\
0(0) \\
2(1) \\
32(12) \\
10(4) \\
14(5)\end{array}$ \\
\hline
\end{tabular}

Table 10 Present reported drug use of survivors and controls

\begin{tabular}{lcc}
\hline Drug & $\begin{array}{l}\text { Survivors } \\
n=349\end{array}$ & $\begin{array}{l}\text { Controls } \\
n=277\end{array}$ \\
\hline Digitalis & $31(9)$ & $10(4)^{* *}$ \\
Diuretics & $98(28)$ & $26(9)^{* * *}$ \\
B blockers & $112(32)$ & $14(5)^{* * *}$ \\
Antihypertensives & $18(5)$ & $3(1)^{* * *}$ \\
Calcium antagonists & $30(9)$ & $9(3)^{* *}$ \\
Nitrates & $101(29)$ & $28(10)^{* * *}$ \\
Non-steroidal anti- & $17(5)$ & $3(1)^{* * *}$ \\
inflammatory drugs & $41(12)$ & $5(2)^{* * *}$ \\
Major and minor tranquillisers & $46(13)$ & $11(4)^{* * *}$ \\
Other miscellaneous drugst & &
\end{tabular}

† Other analgesics, drugs for digestive disorders, anti-asthmatics

* $p<0.05 * 0<0.01$ *** $p<0.001$ controls reported some cardiovascular event. Significantly more survivors reported some further myocardial infarction (26\%), heart surgery $(4 \%)$, thrombosis $(6 \%)$, or admission for other cardiovascular disease $(10 \%)$ than did controls $(6 \%$, $1 \%, 1 \%$, and $1 \%$ respectively).

In table 11 the anxiety scores of survivors are compared with those of controls (in Wales) and with a general population (in England). ${ }^{16}$ Anxiety scores of survivors were higher than those of controls and of the general population for both men and women, although not significantly so in the $75+$ age group. Depression scores are similarly compared in table 12 . Male survivors over age 55 were significantly more depressed than both controls and the general population. Female survivors' scores were not significantly different from controls' scores but they were significantly higher than scores in the general population.

Table 11 Anxiety scores of long term survivors, controls, and a general population

Means \pm standard deviation (numbers)

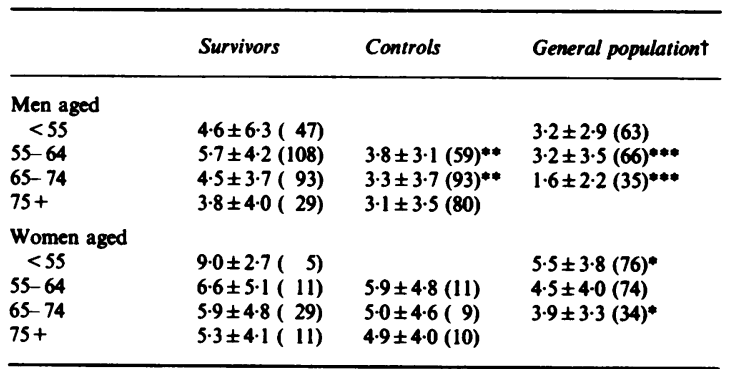

* $p<0.05 \quad * * 0<0.01 \quad * * * p<0.001$

$\uparrow$ Crown and Crisp (1979) 16

Table 12 Depression scores of long term survivors, controls and a general population

Means \pm standard deviation (numbers)

\begin{tabular}{|c|c|c|c|}
\hline & Survivors & Controls & General populationt \\
\hline $\begin{array}{l}\text { Men aged } \\
<54 \\
55-64 \\
65-74 \\
75+\end{array}$ & $\begin{array}{l}2 \cdot 9 \pm 2.9(47) \\
4 \cdot 3 \pm 3 \cdot 2(108) \\
4 \cdot 2 \pm 2 \cdot 9(93) \\
4 \cdot 1 \pm 2.9(29)\end{array}$ & $\begin{array}{l}2.7 \pm 2.8(59)^{* * *} \\
3.6 \pm 3 \cdot 1(92) \\
3.1 \pm 2.3(80)^{*}\end{array}$ & $\begin{array}{l}3 \cdot 1 \pm 2 \cdot 8(62) \\
3 \cdot 4 \pm 2 \cdot 4(63)^{*} \\
3 \cdot 1 \pm 2 \cdot 5(38)^{*}\end{array}$ \\
\hline $\begin{array}{l}\text { Women aged } \\
<54 \\
55-64 \\
65-74 \\
75+\end{array}$ & $\begin{array}{l}6.8 \pm 1.9(5) \\
4.8 \pm 3.2(11) \\
4.7 \pm 3.0(29) \\
4.4 \pm 3.2(11)\end{array}$ & $\begin{array}{l}4.4 \pm 2.8(11) \\
4 \cdot 4 \pm 2 \cdot 1(9) \\
4 \cdot 6 \pm 3.6(10)\end{array}$ & $\begin{array}{l}4 \cdot 1 \pm 2 \cdot 7(76)^{*} \\
4 \cdot 0 \pm 3 \cdot 1(74) \\
4 \cdot 0 \pm 2 \cdot 3(36)^{*}\end{array}$ \\
\hline
\end{tabular}

* $p<0.05 \quad * * * 0<0.001$

+ Crown and Crisp (1979) 16 


\section{Discussion}

This study has shown that long term survivors of acute myocardial infarction have dramatically altered their habits and lifestyles compared with controls over a similar time span. In all questionnaire sections many more survivors reported changes, usually 9-10 years ago (soon after their infarctions) and for mainly medical reasons. Those controls who reported changes usually made the changes more recently and for more general reasons, such as cost or retirement. Moreover, present habits and lifestyles of long term survivors differ quite markedly from those of normal subjects, reported by others.

Controls were slightly older than survivors due to the practical constraints of computerised FPC lists, but this potential bias would reduce differences in habit and lifestyle changes between survivors and controls since changes, for "natural ageing" reasons, were more frequently reported by elderly controls. Secondly, controls were not pursued as vigorously as cases (with only a single mailing), and the self-reported prevalences of angina (12\%) and myocardial infarction (6\%) among controls were higher than in other population-based studies, ${ }^{19}$ suggesting the possibility of some "self-selection" bias among responding controls. This possible bias would, however, also tend to reduce lifestyle differences between survivors and controls.

Many survivors smoked heavily 10 years ago (at the time of their infarction), which supports the now well established hypothesis that smoking is one of the major risk factors of heart disease. ${ }^{20}$ However, many of the survivors who smoked at the time of their infarction gave up or reduced smoking, and the probable reason for such a significant reduction is that patients sought to improve their prognosis, since it has been suggested that reduction in smoking may be beneficial to survival. ${ }^{9-13}$

The dietary changes made by survivors were quite marked, and their present frequencies of eating specific foods were significantly different from both those of our controls and those of the MRC Caerphilly study. ${ }^{17}$ Many survivors modified their diet by reducing total fat and increasing fibre, changes which could result in secondary changes in blood pressure, serum cholesterol and weight which might influence the incidence of further cardiovascular events, although the results of randomised trials are unconvincing. ${ }^{21-23}$ The follow up has shown also that many survivors reduced their weight by quite large amounts, which was probably chiefly the result of altered diets and not of increased exercise, since few survivors increased and most tended to reduce their usual amount of physical exercise. Although there is now some evidence that participation in an exercise rehabilitation programme, either alone or in conjunction with advice on smoking and diet, can improve both physical ability and behavioural outlook, 2425 there was little encouragement in the early 1970s in Wales to enrol in an active exercise rehabilitation programme.

Survivors reported higher drug use than controls not only of "heart-related" drugs, as might be expected, but also of other drugs not specifically associated with heart disease. This may be a reflection of survivors' generally poorer state of health, real or perceived. However, it was noted at interview that several survivors had taken part in the MRC aspirin trial, ${ }^{5}$ which would contribute to the high use of non-steroidal anti-inflammatory drugs.

The anxiety and depression scores demonstrated some residual psychological morbidity 10 years after myocardial infarction, compatible with reports by others of incomplete psychological rehabilitation and residual psychological morbidity. ${ }^{26} 27$ Myocardial infarction is clearly a very frightening experience with long term implications and, while it is possible that these patients may have had higher than averageo scores before infarction, comments by those who were interviewed suggested that it was more likely to have been reaction to infarction and incomplete rehabilitation which resulted in raised scores. Theanxiety score among men aged 65-74 in the Crown and Crisp English sample was significantly lower than among the corresponding Welsh controls. This may be $\overrightarrow{.}$ due to a slight selection bias among our controls, $\infty_{\infty}^{\infty}$ whereby people with some heart disease symptoms (eg, angina) were more likely to respond, or it may reflect a small real cultural difference, confirmation of which would require larger, more representative samples.

This retrospective observational study has shown that a large proportion of long term survivors of myocardial infarction made quite major changes of habits and lifestyles. One should not conclude that all victims of myocardial infarction make such changes, since they were reported by long term survivors. The changes may contribute to survival and, subject to the limitations and biases of differential recall, comparison of responses by spouses of the deceased to the same questionnaire with the responses reported here suggest that some of these factors may have contributed to survival. Other studies have reported benefits of cessation of smoking. ${ }^{9-13}$ Furthermore, circumstantial evidence from interviews suggests that survivors made these considerable changes to reduce their risk of further manifestation or complications of heart disease and in the hope of regaining their health. That such large changes occur suggests that myocardial infarction patients, and perhaps their physicians, perceive the risk factors for primary heart 
disease as risk factors also for further manifestations of the disease ${ }^{8}$ and that attention to these risk factors may improve their prognosis, although the evidence of controlled trials in rehabilitation may not be convincing. ${ }^{25-27}$ For these patients perhaps it is a case of "closing the stable door after the horse has bolted". Nevertheless there may be a health education message relevant to the next cohort of potential myocardial infarction patients: extending knowledge of the major changes in habits and lifestyle achieved voluntarily by patients after myocardial infarction could be a powerful vehicle by which to encourage hypertensive, hypercholesterolaemic, and overweight smokers to reduce their risk of a first myocardial infarction.

We wish to thank many patients and controls for completing questionnaires and Miss $\mathrm{C}$ Linton for statistical assistance. The study was supported by a grant from the Welsh scheme for development of health and social research.

\section{References}

${ }^{1}$ Norris RM, Caughey DE, Deeming LW, et al. Coronary prognostic index for predicting survival after recovery from acute myocardial infarction. Lancet 1970; ii: 485-8.

${ }^{2}$ Merrilees MA, Scott PJ, Norris RM. Prognosis after myocardial infarction: results of 15 year follow up. $\mathrm{Br}$ Med J 1984; 288: 356-9.

${ }^{3}$ Wilhelmsson C, Vedin JA, Wilhelmsen L, et al. Reduction of sudden deaths after myocardial infarction by treatment with alprenolol. Lancet 1974; ii: 1157-9.

${ }^{4} \mathrm{~A}$ multicentre international study: improvement in prognosis of myocardial infarction by long-term beta-adrenoceptor blockade using practolol. $\mathrm{Br}$ Med J 1975; ii: 735-40.

${ }^{5}$ Elwood PC, Cochrane AL, Burr ML, et al. A randomised controlled trial of acetylsalicylic acid in the secondary prevention of mortality from myocardial infarction. $\mathrm{Br}$ Med J 1974; ii: 436-40.

${ }^{6}$ Anturane Reinfarction Trial Research Group. Sulfinpyrazone in prevention of sudden death after myocardial infarction. N Engl J Med 1980; 302: 250-6.

${ }^{7}$ Kallio V, Hamalainen $H$, Hakkila J, Luurila OJ. Reduction of sudden death by multifactorial intervention programme after acute myocardial infarction. Lancet 1979; ii: 1091.

${ }^{8}$ Joint Recommendations by the International Society and Federation of Cardiology Scientific Councils on arteriosclerosis, epidemiology and prevention, and rehabilitation. Secondary prevention in survivors of myocardial infarction. Br Med J 1981; 282: 894-6.
${ }^{9}$ Wilhelmsson C, Vedin JA, Elmfeldt D, et al. Smoking and myocardial infarction. Lancet 1975; i: 415-20.

${ }^{10}$ Mulcahy R, Hickey N, Graham IM, MacAirt J. Factors affecting the 5 year survival rate of men following acute coronary heart disease. Am Heart $J$ 1977; 93: 556-9.

${ }^{11}$ Sparrow D, Dawber TR, Colton T. The influence of cigarette smoking on prognosis after a first myocardial infarction. A report from the Framingham study. J Chron Dis 1978; 31: 425-32.

12 The Coronary Drug Project Research Group. Cigarette smoking as a risk factor in men with a prior history of myocardial infarction. $J$ Chron Dis 1979; 32: 415-25.

${ }^{13}$ Aberg A, Bergstrand R, Johansson S, et al. Cessation of smoking after myocardial infarction. Effects on mortality after 10 years. Br Heart $J$ 1983; 49: 416-22.

14 West RR, Henderson AH. Long term survival of patients mobilised early after acute myocardial infarction. $B r$ Heart J 1985; 53: 243-7.

15 Yarnell JWG, Elwood PC, Sweetnam PM, et al. Caerphilly and Speedwell collaborative heart studies. $J$ Epidemiol Community Health 1984; 38: 259-62.

${ }^{16}$ Crown S, and Crisp AH. The manual of the Crown-Crisp Experiential Index. Hodder and Stoughton. 1979.

17 Yarnell JWG, 1985, personal communication.

18 Yarnell JWG, Fehily AM, Millbank JE, et al. A short dietary questionnaire for use in an epidemiological survey: comparison with weighed dietary records. Hum Nutr Appl Nutr 1983; 37A: 103-12.

${ }^{19}$ Rose G, Tunstall Pedoe HD, Heller RF. UK heart disease prevention project: incidence and mortality results. Lancet 1983; i: 1062-6.

${ }^{20}$ Doll R, Peto R. Mortality in relation to smoking: 20 years' observation on male British doctors. Br Med J 1976; 2: 1525-36.

${ }^{21}$ Leren P. Effect of plasma cholesterol lowering diet in male survivors of myocardial infarction. Acta Med Scand 1966 Suppl $4661-92$.

${ }^{22}$ Medical Research Council Research Committee. Controlled trial of soyabean oil in myocardial infarction. Lancet 1968 ii: 693-700.

${ }^{23}$ Woodhill JM, Palmer AJ, Leelartheapin B, McGilchrist C, Blacket RB. Low fat low cholesterol diet in secondary prevention of coronary heart disease. Adv Exp Med Biol 1978; 109: 317-30.

${ }^{24}$ Carson P, Phillips R, Neophytou M, et al. Exercise after myocardial infarction: a controlled trial. $J R$ Coll Physicians Lond 1982; 16: 147-51.

${ }^{25}$ Young DT, Kottke TE, McCall MM, Blume DA. A prospective study of in-hospital myocardial infarction rehabilitation. J Cardiac Rehab 1982; 2: 32-40.

${ }^{26}$ Stern MJ, Pascale L, Ackerman A. Life adjustment post myocardial infarction. Arch Intern Med 1977; 137: $1680-5$.

${ }^{27}$ Naismith LD, Robinson JF, Shaw GB, McIntyre MM. Psychological rehabilitation after myocardial infarction. Br Med J 1979; 1: 439-66. 